\title{
A Selective Role for Neuronal Activity Regulated Pentraxin in the Processing of Sensory-Specific Incentive Value
}

\author{
Alexander W. Johnson, ${ }^{1,2 *}$ Hans S. Crombag, ${ }^{1,2 *}$ Kogo Takamiya, ${ }^{3,5}$ Jay M. Baraban, ${ }^{3,4}$ Peter C. Holland, ${ }^{1,2}$ \\ Richard L. Huganir, ${ }^{3,5}$ and Irving M. Reti $\mathrm{i}^{3,4}$ \\ ${ }^{1}$ Neurogenetics and Behavior Center and ${ }^{2}$ Department of Psychological and Brain Sciences, Johns Hopkins University, Baltimore, Maryland 21218, \\ ${ }^{3}$ Solomon Snyder Department of Neuroscience, ${ }^{4}$ Department of Psychiatry and Behavioral Sciences, and ${ }^{5}$ Howard Hughes Medical Institute, Johns Hopkins \\ School of Medicine, Baltimore, Maryland 21205
}

Neuronal activity regulated pentraxin (Narp) is a secreted neuronal product which clusters AMPA receptors and regulates excitatory synaptogenesis. Although Narp is selectively enriched in brain, its role in behavior is not known. As Narp is expressed prominently in limbic regions, we examined whether Narp deletion affects performance on tasks used to assess motivational consequences of foodrewarded learning. Narp knock-out (KO) mice were unimpaired in learning simple pavlovian discriminations, instrumental lever pressing, and in acquisition of at least two aspects of pavlovian incentive learning, conditioned reinforcement and pavlovian-instrumental transfer. In contrast, Narp deletion resulted in a substantial deficit in the ability to use specific outcome expectancies to modulate instrumental performance in a devaluation task. In this task, mice were trained to respond on two levers for two different rewards. After training, mice were prefed with one of the two rewards, devaluing it. Responding on both levers was then assessed in extinction. Whereas control mice showed a significant preference in responding on the lever associated with the nondevalued reward, Narp K0 mice responded equally on both levers, failing to suppress responding on the lever associated with the devalued reward. Both groups consumed more of the nondevalued reward in a subsequent choice test, indicating Narp KO mice could distinguish between the rewards themselves. These data suggest Narp has a selective role in processing sensory-specific information necessary for appropriate devaluation performance, but not in general motivational effects of reward-predictive cues on performance.

Key words: reward; immediate early gene; knock-out; mice; pavlovian to instrumental transfer; conditioned reinforcement; reinforcer devaluation

\section{Introduction}

Neuronal activity regulated pentraxin (Narp) is a secreted immediate early gene (IEG) product that coclusters with AMPA receptor subunits and facilitates their aggregation at excitatory synapses. In addition, overexpression of recombinant Narp increases the number of excitatory synapses, suggesting a role for it in excitatory synaptogenesis (Tsui et al., 1996; O’Brien et al., 1999). Moreover, Narp expression is regulated by synaptic activity and psychoactive drugs and has been suggested to play a role in molecular adaptations to drug exposure (Tsui et al., 1996; Reti and Baraban, 2003).

Although Narp is expressed throughout the CNS, its colocalization with orexin in the lateral hypothalamus (Reti et al., 2002) suggests that it may play an important role in motivational func-

Received Aug. 10, 2007; revised 0ct. 18, 2007; accepted 0ct. 18, 2007

This work was supported by National Institutes of Health Grants RR017688 and R01DA016303. We thank Jeffery Sutton and Janna Johnson for excellent technical assistance.

${ }^{*}$ A.W.J. and H.S.C. contributed equally to this work.

Correspondence should be addressed to Dr. Alexander W. Johnson, Department of Psychological and Brain Sciences, Neurogenetics and Behavior Center, Johns Hopkins University, Ames Hall, Room 108, 3400 North Charles Street, Baltimore, MD 21218. E-mail: awj@jhu.edu.

H. S. Crombag's present address: Biological and Clinical Psychology Research Group, The University of Sussex, Brighton BN1 9Q6, UK.

DOI:10.1523/JNEUROSCI.4320-07.2007

Copyright $\odot 2007$ Society for Neuroscience $\quad 0270-6474 / 07 / 2713430-06 \$ 15.00 / 0$ tion (Lu et al., 2002; Reti and Baraban, 2003). Hypothalamic orexin neurons project to several brain regions implicated in various aspects of motivation and reward learning, including the amygdala, nucleus accumbens, ventral tegmental area, and prefrontal cortex (Peyron et al., 1998; Sakurai et al., 1998; Fadel and Deutch, 2002), and Narp itself is expressed in many of these regions as well (Tsui et al., 1996; Lu et al., 2002; Reti et al., 2002). Thus, in this study we evaluated the effects of Narp deletion on performance in three tasks often used to assess emotional or motivational consequences of food-rewarded learning and that, in part, depend on the integrity of these brain regions.

In experiment 1 , after assessing the effects of Narp deletion on the acquisition of pavlovian and instrumental discrimination learning, we examined the ability of pavlovian food-paired cues to modulate the rate of ongoing instrumental responding (pavlovian-instrumental transfer). Many learning theorists assert that cues paired with food acquire learned incentive motivational properties, which would enhance the performance of other foodmotivated behaviors (Rescorla and Solomon, 1967). Similarly, considerable research shows that cues paired with food acquire reinforcement power akin to that of food itself (Mackintosh 1974). Thus, in experiment 2, we examined the effects of Narp deletion on the ability of a food paired cue to serve as a reinforcer to establish new instrumental responding (conditioned rein- 
forcement). Finally, in experiment 3 we examined the effects of Narp deletion on the ability to perform a reinforcer devaluation task in which the spontaneous adjustment of responding appropriate to post-training changes in the motivational significance of the reinforcer is examined (Dickinson and Balleine, 1995). This task assesses the ability of animals to represent sensory and motivational properties of reinforcers, to update those representations when new information is acquired, and to use those updated representations to guide behavior (Pickens and Holland, 2004).

\section{Materials and Methods}

Generation of Narp KO mice. Initially, 129 genomic DNA was prepared by screening of a mouse genomic DNA basal amygdaloid complex library. Genomic DNA regions of the mouse Narp gene were subcloned into pBluescript vector and the targeting vector construct was based on mouse genomic DNA databases. The entire exon 2 was replaced by a neo-resistant gene cassette. ES cell screening and generation of the knock-out mouse line were performed as described previously (Kim et al., 2003; Gardner et al., 2005). Deletion of exon 2 was confirmed by Southern blot and absence of Narp protein in brain was confirmed by Western blot (supplemental Fig. 1, available at www.jneurosci.org as supplemental material).

Subjects. All behavioral testing was conducted with age-matched Narp $\mathrm{KO}$ and wild-type littermate control mice which had been backcrossed four times to the C57BL/6 strain. Mice were generated by breeding Narp heterozygotes at the Johns Hopkins School of Medicine. All experimental procedures were approved by the Institutional Animal Care and Use Committee.

At 4-6 months of age, mice were transferred to the Neurogenetics and Behavior Center, Johns Hopkins University, Baltimore, MD, for behavioral testing. They were housed three or four to a cage under a $12 \mathrm{~h}$ light/dark cycle (lights on from 7:00 A.M. to 7:00 P.M.) and weighed between 25 and $35 \mathrm{~g}$ before food deprivation. Food deprivation began $5 \mathrm{~d}$ before the start of each experiment and continued throughout training. All mice were food deprived to $85 \%$ of their ad libitum weights by limiting access to a single daily meal. Behavioral training and testing were completed in the light cycle between 9:00 A.M. and 5:00 P.M. Experiment 1 was conducted with experimentally naive Narp KO $(n=8$; three males and five females) and wild-type control mice ( $n=8$; three males and five females). Experiment 2 was conducted with naive $\operatorname{Narp} \mathrm{KO}(n=7$; three males and four females) and wild-type control mice $(n=9$; five males and four females). Finally, Experiment 3 was conducted in two replications with naive $\mathrm{KO}(n=14$; six males and eight females $)$ and control mice ( $n=16$; seven males and nine females).

Apparatus. For all three experiments, all mice were trained in eight, identical individual chambers with aluminum front and back walls, clear polycarbonate sides, and a floor made of stainless steel rods (Med Associates, St. Albans, VT). Each chamber was fitted to include a food cup into which $0.1 \mathrm{ml}$ of liquid could be delivered. In experiments 2 and 3 , the apparatus was modified, which allowed the reward to be suctioned off via a vacuum attached to the bottom of the food cup. An infrared photocell placed inside the food cup monitored time spent and number of entries into the food cup. Retractable ultrasensitive mouse levers (Med Associates) were available on the left and right sides of the food cup in experiments 1 and 3. A speaker that delivered either a $3 \mathrm{kHz}$ tone or white noise (amplitude set $5 \mathrm{~dB}$ above background; $\sim 80 \mathrm{~dB}$ ), and a heavy duty $10 \mathrm{~Hz}$ clicker module were mounted on the outside of the chamber on the wall opposite the food cup. Ambient illumination for the chamber was provided by a $28 \mathrm{~V}, 100 \mathrm{~mA}$ house light mounted on the inside wall of the sound attenuating chamber. During the conditioned reinforcement testing phase of experiment 2, two nose-poke devices were placed at the locations of the two levers used in experiments 1 and 3. Each nose-poke device contained an illuminated yellow stimulus light-emitting diode located at the rear of the recessed hole and a photo beam sensor to monitor nose-poke entries. An IBM-compatible computer equipped with Med-PC software (Med Associates) controlled and recorded all stimuli and responses.
Experiment 1: behavioral training procedures. All mice first received two 40 min daily food cup training sessions to train them to collect rewards $(0.1 \mathrm{ml}$ delivery of $10 \% \mathrm{w} / \mathrm{v}$ sucrose solution for $\sim 5 \mathrm{~s})$. Rewards were delivered to the food cups on a random time (RT) $30 \mathrm{~s}$ schedule.

Mice then received single daily $40 \mathrm{~min}$ pavlovian training sessions. For the first three sessions the procedure consisted of pseudorandom presentations of five, 2 min rewarded paired cues (CS+; either tone or clicker) and five 2 min nonreward paired cues, with a 2 min variable intertrial interval (ITI). For half the mice in each group, sucrose was delivered to the food cup on an RT 30 s schedule during tone (CS+), but not clicker (CS - ) presentations, whereas for the remaining mice, the clicker served as the CS + and the tone as CS-. At the end of each CS+ presentation, any remaining sucrose was removed. During pavlovian sessions the levers were retracted from the chambers.

Next, the mice were trained to press one of the levers. Instrumental lever-press training began with a single $30 \mathrm{~min}$ session. For half the mice left-lever responses were designated active lever presses and resulted in delivery of sucrose reward, whereas right-lever responses were designated inactive and did not result in reward delivery. For the remaining mice these response assignments were reversed. To facilitate the initial acquisition of responding, a small amount of sweetened milk solution was placed on the active lever at the beginning of the first session only. For the first three sessions of instrumental training reward was made available on a continuous schedule of reinforcement (i.e., each active lever response resulted in reward delivery). Next, the mice received alternating sessions of instrumental and pavlovian training (with the total number of CS + and CS - trials reduced to eight; resulting in a $32 \mathrm{~min}$ session). During instrumental training the reward was available, first on a variable interval (VI) $30 \mathrm{~s}$ schedule for three sessions, and finally on a VI $60 \mathrm{~s}$ schedule for the remaining instrumental sessions. Training was completed when all mice received 12 sessions each of pavlovian and instrumental training.

Finally, pavlovian to instrumental transfer was tested in extinction, that is, in the absence of any sucrose deliveries. A single session began with the extension of both levers into the chamber. As the mice pressed the levers, $5 \mathrm{CS}+$ and $5 \mathrm{CS}$ - trials were delivered separately with a fixed 2 min intertrial interval separating stimulus presentation. We expected pavlovian-instrumental transfer to be expressed as an augmentation of the rate of lever pressing by CS + but not CS- .

Experiment 2: behavioral training procedures. After food cup training, identical to that received by the mice in experiment 1 , the mice received 10 sessions of pavlovian conditioning. Each session was $\sim 30 \mathrm{~min}$ long and consisted of 1210 s presentations each of a $3 \mathrm{kHz}$ tone and of a white noise, with a variable ITI of $60 \mathrm{~s}$. For half the mice in each group sucrose was delivered to the food cup for the final $7 \mathrm{~s}$ of the tone (CS+), but not for the noise (CS-). For the remaining mice the noise served as the CS+ and the tone served as CS-. Any sucrose remaining at the end of CS+ presentation was vacuumed out at that time. CS + and CS - trials were intermixed in pseudorandom sequences determined by the computer.

Finally, the ability of the CS + and CS - to serve as conditioned reinforcers for the acquisition of an instrumental nose-poke responses was assessed in a single $40 \mathrm{~min}$ conditioned reinforcement test session. For half the mice in each group, each nose-poke to the left port resulted in the brief ( $3 \mathrm{~s}$ ) presentation of the tone cue, and each right-nose poke response produced a $3 \mathrm{~s}$ noise presentation. For the remaining mice, the response-stimulus contingencies were reversed. The pavlovian conditioning histories of tone and noise (as CS + or CS-) were also counterbalanced with respect to left or right nose poke responses. Nose-pokes made during a cue presentation were recorded but had no programmed consequences. If the CS + had acquired the ability to serve as a conditioned reinforcer in the pavlovian training phase, then more nose pokes that produced that stimulus would be performed than nose-pokes that produced the previously nonreinforced CS-.

Experiment 3: behavioral training procedures. Food cup training was identical to that of the previous 2 experiments except that in one session the reward was a $0.1 \mathrm{ml}$ orange-flavored sucrose solution ("orange") and in the other session a $0.1 \mathrm{ml}$ grape-flavored sucrose solution ("grape"). The order of the two sessions was counterbalanced. The solutions were $0.1 \%$ Koolaid brand flavorings in $10 \%$ sucrose $(\mathrm{w} / \mathrm{v})$. 
Mice then received two instrumental training sessions per day, separated by $\sim 2 \mathrm{~h}$, one with only the left lever present and one with only the right lever present, with the order of the two sessions alternating daily. For half the mice in each group, left lever responses resulted in delivery of grape and responses on the right lever produced delivery of orange. The remaining mice were assigned the opposite response-outcome contingencies. For the first $2 \mathrm{~d}$ mice were given 60 min sessions in which each response was reinforced. For the remaining $8 \mathrm{~d}$ the session duration was reduced to $20 \mathrm{~min}$ and reward was delivered on a random ratio (RR) 5 schedule (i.e., on average every five responses resulted in reward delivery) on days 3 and 4, and RR10 on days 5-8, and an RR15 on days 9 and 10 . Thus, mice were given a total of 10 sessions of instrumental training on each lever.

The next day, mice received sensory-specific devaluation treatment by prefeeding each mouse with one of the two outcomes for a $2 \mathrm{~h}$ period. Each mouse was placed in a separate homecage, with a cube filled with 2 $\mathrm{ml}$ of either grape or orange, fully counterbalanced across the previous response-outcome contingencies. The experimenter closely monitored and recorded reward consumption during this phase. As the solution was consumed, it was replaced in $1 \mathrm{ml}$ increments to ensure continuous reward availability for each mouse.

Immediately after the devaluation treatment, the mice were given a 30 min extinction test session in the experimental chamber during which responses were not reinforced with reward delivery. Unlike in training, both levers were available in this test session. To the extent that responding was controlled by the current value of the reward anticipated after each of the two responses (left and right lever presses), mice would preferentially perform the response that previously had been reinforced with the reward that had not been prefed (i.e., the nondevalued response).

Finally, the effectiveness of the prefeeding devaluation treatment in altering the mice's preference for the rewards themselves was assessed. On completion of prefeeding identical to that used previously, the mice were given access to two cubes, one containing $2 \mathrm{ml}$ of the prefed reward and other containing $2 \mathrm{ml}$ of the other reward. Mice were given $30 \mathrm{~min}$ to consume each reward, with the expectation that consumption would be greater for the nondevalued reward.

\section{Results}

Experiment 1

Deletion of Narp had no effect on instrumental or pavlovian conditioning, or on pavlovian to instrumental transfer. Figure $1 a$ shows the acquisition of instrumental lever press responding. Both WT and KO mice increased their rate of responding on the reward-producing (active) lever. A group by session ANOVA of active lever responses showed a significant effect of session $\left(F_{(11,154)}=11.19 ; p<0.001\right)$, but no effect of group $\left(F_{(1,14)}=\right.$ $0.35 ; p=0.57)$ or group by session interaction $\left(F_{(11,154)}=0.49\right.$; $p=0.91)$. A similar analysis conducted on the inactive response revealed a small but significant change in responding on the inactive lever (effect of session; $F_{(11,154)}=3.194 ; p<0.001$ ), but no effect of group $\left(F_{(1,14)}=1.09 ; p=0.31\right)$ or interaction between the factors $\left(F_{(11,154)}=1.26 ; p=0.25\right)$.

Because we used long-duration cues with random delivery of pavlovian reinforcement it was not possible to obtain a record of pavlovian conditioned responding uncontaminated by reward presentation. Thus, we report pavlovian food cup responding displayed during the extinction test (Fig. 1b). Deletion of Narp had no effect on pavlovian food cup responding; both WT and mutant mice readily approached the food cup during the previously rewarded CS +, but not during ITI periods. This impression was confirmed by a two-way ANOVA showing no effect of group $\left(F_{(1,14)}=0.0002 ; p=0.98\right)$, a main effect of stimulus $\left(F_{(2,28)}=\right.$ $11.56 ; p<0.001)$, but no interaction between the factors $\left(F_{(2,28)}\right.$ $=1.56 ; p=0.23)$. Bonferroni's post hoc tests revealed more food cup behavior during CS+ periods than during the ITIs for both WT $\left(t_{(7)}=2.61 ; p<0.05\right)$ and mutant mice $\left(t_{(7)}=3.78 ; p<\right.$
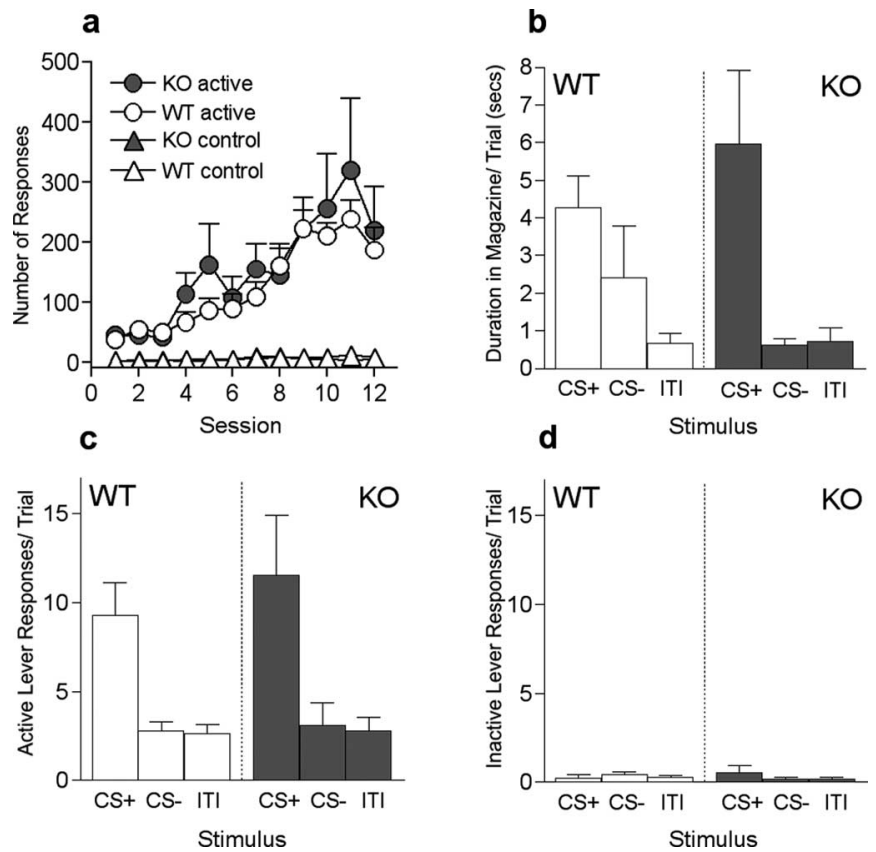

Figure 1. Instrumental training and transfer test performance in Narp WT and KO mice in experiment 1. $\boldsymbol{a}$, Total responses for active (circles) and inactive control levers (triangles) for both WT (open shapes) and $\mathrm{KO}$ mice (closed shapes) during the instrumental training phase. $\boldsymbol{b}$, Duration in food cup per trial for $\mathrm{CS}+, \mathrm{CS}-$, and no stimulus (ITI) presentations during the test stage, for both WT (open bars) and KO mice (closed bars). c, Total active lever responses per trial during presentations of $\mathrm{CS}+, \mathrm{CS}-$, and ITI periods, for both WT (open bars) and KO mice (closed bars). $\boldsymbol{d}$, Total inactive lever responses (per trial) during presentations of CS + CS- , and ITI periods, for both WT (open bars) and KO mice (closed bars). Error bars indicate SEM.

$0.01)$, but not during the CS - compared with ITIs in either WT $\left(t_{(7)}=1.07 ; p>0.05\right)$ or mutant mice $\left(t_{(7)}=0.054 ; p>0.05\right)$.

The data of primary interest (Fig. 1c) are the effects of presenting the pavlovian CS + or CS- on the rate of instrumental responding on the active lever in the extinction test session. The pavlovian rewarded cue $(\mathrm{CS}+)$ augmented ongoing instrumental performance to a similar extent in both mutant and WT mice, relative to responding during either the CS - cue or the ITI. Thus, Narp is not critical to the display of pavlovian-instrumental transfer, a frequently used index of the acquisition of motivational significance to pavlovian CSs. A group by stimulus (CS+, CS - , or ITI) ANOVA showed a main effect of stimulus $\left(F_{(2,28)}=\right.$ $24.7 ; p<0.0001)$, but no effect of group $\left(F_{(1,14)}=0.22 ; p=0.64\right)$ or group by stimulus interaction $\left(F_{(2,28)}=0.44 ; p=0.64\right)$. Bonferroni post hoc tests revealed significantly greater responding during CS + than during CS - for both mutant $\left(t_{(7)}=4.79 ; p<\right.$ $0.001)$ and WT mice $\left(t_{(7)}=3.67 ; p<0.01\right)$. Additionally, response rates were significantly higher during the CS + when compared with the ITI period for both mutant $\left(t_{(7)}=4.97 ; p<0.001\right)$ and WT mice $\left(t_{(7)}=3.77 ; p<0.01\right)$. In contrast to active lever responses, responding on the inactive lever was infrequent in both groups and was not affected by stimulus delivery ( $F$ values $<1$; $p$ values $>0.69$ ) (Fig. $1 d$ ).

\section{Experiment 2}

Narp deletion had no effect on the acquisition of pavlovian discrimination learning, and furthermore, it did not affect the acquisition of a new instrumental response that was reinforced by the conditioned reinforcing properties of the pavlovian CS+. Mutant and WT mice showed similar acquisition of pavlovian food cup responding (Fig. 2a). A group $\times$ stimulus (CS + or 

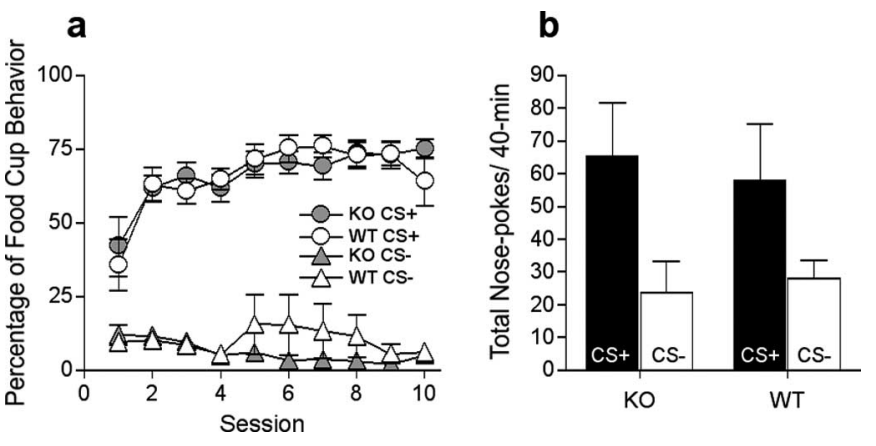

Figure 2. Performance of Narp WT and KO mice in experiment 2. $\boldsymbol{a}$, Percentage of time spent in the food cup during $C S+$ and $C S$ - during pavlovian training. $\boldsymbol{b}$, Total active nose-poke responses to the port that resulted in $C S+$ (closed bars) and $C S$ - (open bars) presentations in the conditioned reinforcement test. Error bars indicate SEM.

CS - ) by session ANOVA showed significant effects of stimulus $\left(F_{(1,14)}=236.62 ; p<0.001\right)$, session $\left(F_{(9,126)}=4.42 ; p<0.001\right)$, and a significant stimulus by session interaction $\left(F_{(9,126)}=22.72\right.$; $p<0.001)$, but no significant effects or interactions involving group ( $F$ values $<1.13$; $p$ values $>0.351$ ).

The primary data of experiment 2 , the results of the conditioned reinforcement test, are depicted in Figure $2 b$. Both groups of mice readily acquired and maintained a novel instrumental nose-poke response to obtain brief presentations of the CS+. Notably, no primary (sucrose) rewards were delivered in this test, so this behavior was reinforced solely by the incentive properties of the CS+ learned during previous pavlovian training. Importantly, more nose-pokes were directed to the port that produced presentations of the CS+ than to the port that produced CSpresentations. A group by response type (CS + producing or CSproducing) ANOVA showed a main effect of response type $\left(F_{(1,14)}=6.91, p<0.05\right)$ but no effect of group $\left(F_{(1,14)}=0.018\right.$, $p=0.89)$ or group $\times$ response type interaction $\left(F_{(1,14)}=0.18\right.$, $p=0.67)$. The results from experiments 1 and 2 collectively show that the deletion of Narp does not affect the ability of a pavlovian $\mathrm{CS}+$ to elicit simple food cup behavior, enhance ongoing instrumental performance (PIT), or reinforce the acquisition of new nose-poke responding (i.e., act as a conditioned reinforcer).

\section{Experiment 3}

As in experiment 1, Narp deletion had no effect on the acquisition of instrumental lever pressing. However, it had a profound effect on performance in the devaluation task. Figure $3 a$ shows the acquisition of instrumental lever pressing, for both the rewards (one to-be devalued later and one not). Mutant and WT mice both readily acquired instrumental responding. Before the devaluation test, the to-be-devalued and nondevalued responses did not differ in frequency for either group. A group by response type (to-be-devalued vs nondevalued) by session ANOVA revealed a main effect of session $\left(F_{(9,252)}=66.5 ; p<0.0001\right)$, but no effect of response type $\left(F_{(1,28)}=1.72 ; p=0.19\right)$ or group $\left(F_{(1,28)}=0.189\right.$; $p=0.67)$. However, there was a significant response type by session interaction $\left(F_{(9,252)}=2.35 ; p<0.05\right)$. Additional analysis of that interaction by examining the simple main effects of response type for each session revealed a significant effect of response type for the first two sessions only (smallest $F$ value, session $\left.1 ; F_{(1,28)}=6.71 ; p<0.05\right)$. Importantly, the group by response interaction was not significant $\left(F_{(1,28)}=1.99 ; p=0.17\right)$.

Figure $3 b$ shows the data of primary interest, those from the postdevaluation test of instrumental responding, in which mice could respond to either lever, but received no rewards. In WT mice, prefeeding of one reward resulted in preferential responding on the lever that had produced the other, nondevalued, reward in training. This result indicated that WT mice could use the devaluation experience to update a representation of the value of the prefed reward, and use that information to direct subsequent instrumental performance. In contrast, mutant mice showed equivalent levels of responding on both levers, suggesting that they were unable to process the altered reward information and modify their instrumental performance accordingly. A group by response type ANOVA showed a main effect of response type $\left(F_{(1,28)}=6.48 ; p<0.05\right)$, no main effect of group $\left(F_{(1,28)}=0.48\right.$; $p=0.83)$, but, most important, a significant group by response type interaction $\left(F_{(1,28)}=11.9 ; p<0.05\right)$. Tests of the simple main effects of response type (which indexed the devaluation effect) revealed a significant effect for WT $\left(F_{1,28)}=19.22 ; p<\right.$ $0.001)$, but not mutant mice $\left(F_{(1,28)}=0.379 ; p=0.54\right)$. Thus, control mice showed a clear devaluation effect, whereas mutant mice showed no evidence for such an effect.

These conclusions were confirmed by a minute by minute analysis of responding during the $30 \mathrm{~min}$ test phase (Fig. $3 d, e$ ). Wild-type control mice showed preferential responding on the lever associated with the nondevalued reward, especially in early portions of the test (Fig. 3d). In contrast, mutant mice responded on both levers at a similar rate throughout the devaluation extinction test (Fig. 3e). A three-way ANOVA with factors of group by response type by time bin, revealed a main effect of time bin $\left(F_{(29,812)}=31.6 ; p<0.0001\right)$, a marginally significant effect of response type $\left(F_{(1,28)}=4.02 ; p=0.05\right)$, no effect of group $\left(F_{(1,28)}\right.$ $=0.001 ; p=1.0)$, but a significant interaction between these latter two factors $\left(F_{(1,28)}=8.51 ; p<0.01\right)$. Importantly, there was a marginally significant three-way interaction of group, response type and time bin $\left(F_{(29,812)}=1.46 ; p=0.05\right)$. To interpret the three-way interaction, separate ANOVAs were conducted for each group, with within-subject factors of response type by time bin. For WT mice, the analysis revealed a main effect of response type $\left(F_{(1,15)}=11.13 ; p<0.01\right)$, time bin $\left(F_{(29,435)}=18.08 ; p<\right.$ $0.0001)$, and a significant interaction between the two factors $\left(F_{(29,435)}=2.18 ; p<0.001\right)$. A similar comparison with $\mathrm{KO}$ mice revealed a main effect of time bin $\left(F_{(29,377)}=14.2 ; p<0.0001\right)$, but no effect of response type $\left(F_{(1,13)}=0.483 ; p=0.49\right)$, and no interaction between the factors $\left(F_{(29,377)}=0.43 ; p=0.99\right)$.

The lack of a devaluation effect in $\mathrm{KO}$ mice was not attributable to differences in reward consumption during the $2 \mathrm{~h}$ prefeeding treatment before the devaluation extinction test, because consumption did not differ significantly $\left(t_{(28)}=0.451 ; p=\right.$ $0.436)$ between WT $(3.90 \pm 0.34 \mathrm{~g})$ and $\mathrm{KO}(4.14 \pm 0.40 \mathrm{~g})$ mice. Furthermore, the results of the reward choice consumption test, given after another prefeeding experience, show that the prefeeding experience affected reward preference similarly in WT and KO mice (Fig. 3c). Because of an error in data recording, the results for this test were unavailable for the mice in the second replication. However, the data from the remaining mutant $(n=$ 7 ) and WT mice $(n=7)$ revealed that both consumed less of the devalued (prefed) reward than of the nondevalued reward. A group by reward type (devalued or nondevalued) ANOVA showed a main effect of food type $\left(F_{(1,12)}=7.63 ; p<0.05\right)$, but no effect of group $\left(F_{1,12)}=0.138 ; p=0.72\right)$ or group by food type interaction $\left(F_{(1,12)}=0.04 ; p=0.95\right)$. Thus, the mutant mice were unimpaired in their ability to discriminate the two rewards, and in their sensitivity to the prefeeding treatment as a means of temporarily altering food preferences. Instead, Narp deletion apparently affected the mice's ability to process that new reward 
value in memory or to use that information to appropriately guide previously learned behavior.

\section{Discussion}

Mice with global deletion of Narp were unimpaired in learning simple pavlovian discriminations, instrumental lever pressing, and in the acquisition of at least two aspects of pavlovian incentive learning. Mutant mice were normal both in their ability to use the pavlovian CS to modulate the performance of a previously established instrumental response (pavlovianinstrumental transfer, experiment 1) and in the power of such a CS to serve as the reinforcer for the acquisition of a new instrumental response (conditioned reinforcement, experiment 2). Thus, Narp is not critical to simple food-based associative learning (Fig. $1 b$ ) nor to the acquisition of two motivational functions acquired via such learning. In contrast, Narp deletion resulted in a substantial deficit in the ability to use specific outcome expectancies to modulate instrumental performance in a devaluation task (experiment 3 ).

Performance in the devaluation task demands that mice acquire sensoryspecific (e.g., taste) reward expectancies associated with each response, alter the motivational value of one of those reward expectancies as a result of prefeeding, and use this updated representation of the expected reward value to guide instrumental responding in the test session, in which the rewards themselves are absent. The results of the final reward choice test showed that the Narp KO mice altered their flavor preferences after prefeeding in the same manner as WT mice. Thus, their failure to show selective reduction of responding directed to the lever that previously produced the now-devalued reward indicates that Narp is important for some aspect of processing outcome expectancies. For example, $\mathrm{KO}$ mice may not have represented the rewards in sufficient sensory detail to form distinguishable response 1 -grape and response 2 -orange associations (i.e., response-outcome associations). Alternatively, $\mathrm{KO}$ mice may have been unable to modify the value of the representation of the prefed reward, or to use that updated representation to cue appropriate responding. Notably, the transfer and conditioned reinforcement procedures used here in experiments 1 and 2 , which used only a single reinforcer and hence did not demand the use of sensory-specific outcome expectancies, were unaffected by Narp deletion. Thus, it would be valuable to determine the effects of Narp deletion on performance in versions of these latter tasks that require the representation of multiple specific outcomes (Blundell et al., 2001; Holland, 2004).

Lesion and inactivation studies in rats have identified brain circuits needed for the successful completion of each of the tasks used in this study. For example, with single-reinforcer procedures, like those used here, the display of pavlovian-instrumental transfer critically depends on the function of the amygdala central nucleus (CeA) (Hall et al., 2001; Holland and Gallagher, 2003), the ventral tegmental area (VTA) (Murschall and Hauber, b
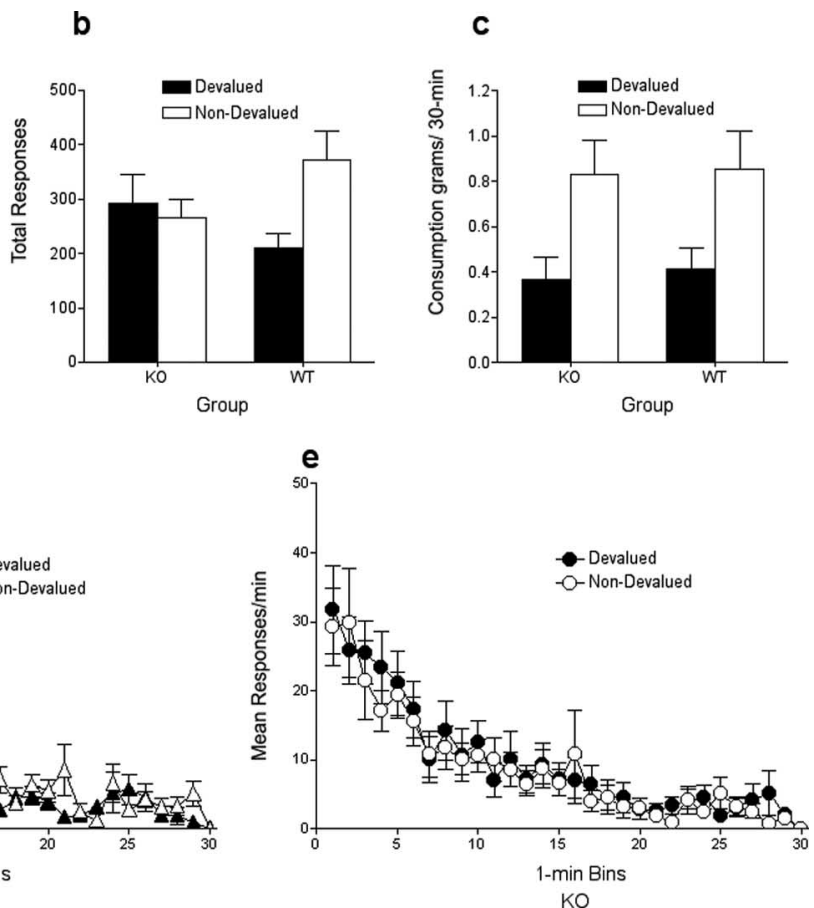

$\mathrm{KO}$

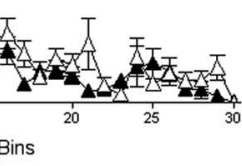

WT

$\triangle$ Devalued $-\leftarrow$ Non-Devalued

Figure 3. Instrumental conditioning and reinforcer-selective devaluation in Narp WT and KO mice. $\boldsymbol{a}$, Total lever-press resession responding (in 1 min bins) in WT mice for devalued (closed triangles) and nondevalued (open triangles) responses. $\boldsymbol{e}$, Test session responding in $\mathrm{KO}$ mice for devalued (closed circles) and nondevalued (open circles) responses. Error bars indicate SEM.

2006) and the ventral striatal nucleus accumbens (Hall et al., 2001), which Hall et al. (2001) suggested might form a circuit critical to positive incentive learning. Similarly, conditioned reinforcement involves the nucleus accumbens, the orbitofrontal cortex (OFC) (Pears et al., 2003) and basolateral amygdala (BLA), a region that shows substantial expression of Narp constitutively (Tsui et al., 1996). Nevertheless, mice with Narp deletion were unimpaired in these two tasks, suggesting that under these behavioral conditions Narp expression plays little role in the functions of these particular brain systems.

In contrast, successful performance in the devaluation task was found to require Narp. GABA-mediated inhibition (Wellman et al., 2005), infusions of anisomycin (Wang et al., 2005), and excitotoxic lesions (Hatfield et al., 1996; Blundell et al., 2001) to the BLA have all been shown to suppress devaluation effects. Similarly, damage to the medial dorsal thalamic nuclei (Corbit et al., 2003) and regions of the prefrontal cortex, especially the prelimbic area (Balleine and Dickinson, 1998; Corbit and Balleine, 2003), result in deficits in instrumental devaluation performance. Given that integrity of the BLA is necessary for conditioned reinforcement, it is possible that Narp is critical to the normal functioning of only a subpopulation of BLA neurons that are key to representing or using sensory-specific motivational information about reinforcers, but which are not crucial to conditioned reinforcement or transfer in the single-reinforcer versions of the tasks used here. In that case, one might anticipate that Narp KOs would also show deficits in performance in reinforcer-specific transfer (Holland, 2004), which is known to depend on BLA function as well (Blundell et al., 2001). However, it is of particular interest that substantial Narp expression has been noted in the prefrontal 
cortex (Tsui et al., 1996; Lu et al., 2002), and specifically in prelimbic (PL) regions (Lu et al., 2002), because rats with damage to this structure show a pattern of behavioral deficits similar to that exhibited by Narp KOs in the present report. That is, rats with PL lesions are impaired in their performance in devaluation tasks (Balleine and Dickinson, 1998; Corbit and Balleine, 2003), but not in conditioned reinforcement (Pears et al., 2003) or transfer (Corbit and Balleine, 2003). Therefore, further consideration of Narp function in prelimbic cortex is particularly relevant.

Because Narp has been implicated in regulating AMPA receptor trafficking, these behavioral findings are consistent with those of previous studies by Johnson et al. (2005), which demonstrated that mice lacking the AMPA receptor GluR1 subunit are deficient in devaluing instrumental responding for a food reward. Although Narp has been implicated in clustering AMPA receptors, its role in mediating synaptic plasticity remains to be fully clarified. As these mice performed normally in several classical assays of learning and memory reported here, it is not surprising that conventional measures of hippocampal long term potentiation are intact in Narp KO mice and in mice lacking Narp as well as the two other neuronal pentraxins, NP1 and NPR (Bjartmar et al., 2006). However, our detection of selective deficits suggest that Narp plays an important role in other types of synaptic plasticity critical for adjusting behavioral responses in the face of devaluation. Recent studies have implicated other effector IEGs including Arc (Chowdhury et al., 2006) and Homer (Fourgeaud et al., 2004) in AMPA receptor endocytosis and long term depression. Conceivably, successful devaluation of a food reward, unlike the other forms of learning evaluated in this study, involves suppression of brain circuits mediated by Narp-regulated AMPA receptor endocytosis.

In summary, the results of this study suggest that Narpmediated neurotransmission has a selective role in encoding sensory-specific motivational value, but not the general motivational effects of rewarded cues on performance. Although the precise mechanisms by which Narp regulates these effects is unknown, they may involve the regulation by Narp of AMPA receptor trafficking in brain regions subserving reward learning.

\section{References}

Balleine BW, Dickinson A (1998) Goal-directed instrumental action: contingency and incentive learning and their cortical substrates. Neuropharmacology 37:407-419.

Bjartmar L, Huberman AD, Ullian EM, Rentería RC, Liu X, Xu W, Prezioso J, Susman MW, Stellwagen D, Stokes CC, Cho R, Worley P, Malenka RC, Ball S, Peachey NS, Copenhagen D, Chapman B, Nakamoto M, Barres BA, Perin MS (2006) Neuronal pentraxins mediate synaptic refinement in the developing visual system. J Neurosci 26:6269-6281.

Blundell P, Hall G, Killcross S (2001) Lesions of the basolateral amygdala disrupts selective aspects of reinforcer representation in rats. J Neurosci 26:9018-9026.

Chowdhury S, Shepherd JD, Okuno H, Lyford G, Petralia RS, Plath N, Kuhl D, Huganir RL, Worley PF (2006) Arc/Arg3.1 interacts with the endocytic machinery to regulate AMPA receptor trafficking. Neuron 52:445-459.

Corbit LH, Balleine BW (2003) The role of prelimbic cortex in instrumental conditioning. Behav Brain Res 146:145-157.

Corbit LH, Muir JL, Balleine BW (2003) Lesions of mediodorsal thalamus and anterior thalamic nuclei produce dissociable effects on instrumental conditioning in rats. Eur J Neurosci 18:1286-1294.

Dickinson A, Balleine B (1995) Motivational control of instrumental action. Cur Dir Psychol Sci 4:162-167.

Fadel J, Deutch AY (2002) Anatomical substrates of orexin-dopamine interactions: lateral hypothalamic projections to the ventral tegmental area. Neurosci 111:379-387.

Fourgeaud L, Mato S, Bouchet D, Hémar A, Worley PF, Manzoni OJ (2004)
A single in vivo exposure to cocaine abolishes endocannabinoid-mediated long-term depression in the nucleus accumbens. J Neurosci 24:6939-6945.

Gardner SM, Takamiya K, Xia J, Suh JG, Johnson R, Yu S, Huganir RL (2005) Calcium-permeable AMPA receptor plasticity is mediated by subunitspecific interactions with PICK1 and NSF. Neuron 45:903-915.

Hall J, Parkinson JA, Connor TM, Dickinson A, Everitt BJ (2001) Involvement of the central nucleus of the amygdala and nucleus accumbens core in mediating pavlovian influences on instrumental behaviour. Eur J Neurosci 13:1984-1992.

Hatfield T, Han JS, Conley M, Gallagher M, Holland PC (1996) Neurotoxic lesions of the basolateral, but not central, amygdala interfere with pavlovian second order conditioning and reinforcer devaluation effects. J Neurosci 16:5256-5265.

Holland PC (2004) Relations between pavlovian-instrumental transfer and reinforcer devaluation. J Exp Psychol Anim Behav Process 30:104-117.

Holland PC, Gallagher M (2003) Double dissociation of the effects of lesions of basolateral and central amygdala on CS-potentiated feeding and pavlovian-instrumental transfer. Eur J Neurosci 17:1680-1694.

Johnson AW, Bannerman DM, Rawlins NP, Sprengel R, Good MA (2005) Impaired outcome-specific devaluation of instrumental responding in mice with a targeted deletion of the AMPA receptor glutamate receptor 1 subunit. J Neurosci 25:2359-2365.

Kim JH, Lee HK, Takamiya K, Huganir RL (2003) The role of synaptic GTPase activating protein in neuronal development and synaptic plasticity. J Neurosci 23:1119-1124.

Lu W, Marinelli M, Xu D, Worley PF, Wolf ME (2002) Amphetamine and cocaine do not increase Narp expression in rat ventral tegmental area, nucleus accumbens or prefrontal cortex, but Narp may contribute to individual differences in responding to a novel environment. Eur J Neurosci 15:2027-2086.

Mackintosh N (1974) The psychology of animal learning. London: Academic.

Murschall A, Hauber W (2006) Inactivation of the ventral tegmental area abolished the general excitatory influence of pavlovian cues on instrumental performance. Learn Mem 13:123-126.

O’Brien R, Xu D, Petralia R, Oswald S, Huganir R, Worley P (1999) Synaptic clustering of AMPA receptors by the extracellular immediate-early gene product Narp. Neuron 23:309-323.

Pears A, Parkinson JA, Hopewell L, Everitt BJ, Roberts AC (2003) Lesions of the orbitofrontal but not medial prefrontal cortex disrupt conditioned reinforcement in primates. J Neurosci 23:11189-11201.

Peyron C, Tighe DK, van den Pol AN, de Lecea L, Heller HC, Sutcliffe JG, Kilduff TS (1998) Neurons containing hypocretin (orexin) project to multiple neuronal systems. J Neurosci 18:9996-10015.

Pickens CL, Holland PC (2004) Conditioning and cognition. Neurosci Biobehav Rev 28:651-661.

Rescorla RA, Solomon RL (1967) Two process learning theory: relationships between classical conditioning and instrumental learning. Psychol Rev 74:151-182.

Reti IM, Baraban J (2003) Opiate withdrawal induces Narp in the extended amygdala. Neuropsychopharmacology 23:1606-1613.

Reti IM, Reddy R, Worley PF, Baraban JM (2002) Selective expression of Narp, a secreted neuronal pentraxin, in orexin neurons. J Neurochem 82:1561-1565.

Sakurai T, Amemiya A, Ishii M, Matsuzaki I, Chemelli RM, Tanaka H, Williams SC, Richarson JA, Kozlowski GP, Wilson S, Arch JR, Buckingham RE, Haynes AC, Carr SA, Annan RS, McNulty DE, Liu WS, Terrett JA, Elshourbagy NA, Bergsma DJ, et al. (1998) Orexins and orexin receptors: a family of hypothalamic neuropeptides and $\mathrm{G}$ protein-coupled receptors that regulate feeding behavior. Cell 92:573-585.

Tsui CC, Copeland NG, Gilbert DJ, Jenkins NA, Barnes C, Worley PF (1996) Narp, a novel member of the pentraxin family, promotes neurite outgrowth and is dynamically regulated by neuronal activity. J Neurosci 16:2463-2478.

Wang SH, Ostlund SB, Nader K, Balleine BW (2005) Consolidation and reconsolidation of incentive learning in the amygdala. J Neurosci 25:830-835.

Wellman LL, Gale K, Malkova L (2005) GABAA-mediated inhibition of basolateral amygdala blocks reward devaluation in macaques. J Neurosci $25: 4577-4586$ 